\title{
Digital geologic map of part of the Thompson Falls 1:100,000 quadrangle, Idaho
}

\author{
by Reed S. Lewis ${ }^{1}$ and Pamela D. Derkey ${ }^{2}$
}

Open-File Report 99-438

Prepared in cooperation with the Idaho Geological Survey

1999

This report is preliminary and has not been reviewed for conformity with U.S. Geological Survey editorial standards or with the North American Stratigraphic Code. Any use of trade, product, or firm names is for descriptive purposes only and does not imply endorsement by the U.S. Government. The digital database is not meant to be used or displayed at any scale larger than 1:100,000 (e.g., 1:62,500 or 1:24,000).

\section{U.S. DEPARTMENT OF THE INTERIOR U.S. GEOLOGICAL SURVEY}

1 Idaho Geological Survey, University of Idaho, Moscow, ID 83844

2 U.S. Geological Survey, Spokane, WA 99201 


\section{Table of Contents}

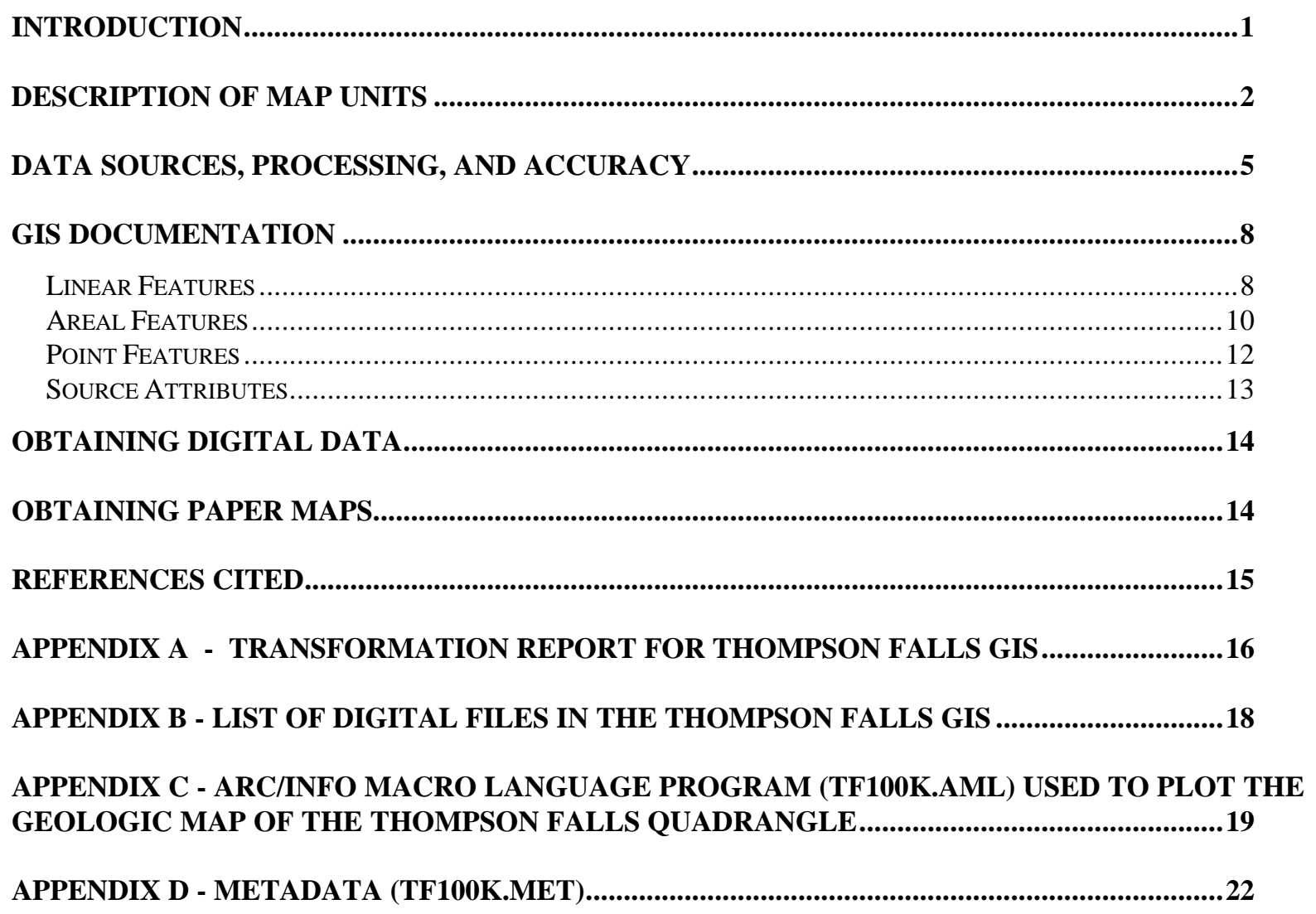

\section{List of Figures}

Figure 1. Index map showing the geographic extent of the mapped area following page 1

Figure 2. Location map showing sources of compilation data___ 3

Figure 3. Explanation for the simplified digital geologic map of the Thompson Falls quadrangle, ID _ 6

Figure 4. Simplified digital geologic map of the Thompson Falls 1:100,000 quadrangle, ID___ 7

Figure 5: Relationships between feature attribute tables and look-up tables. 9 


\section{Introduction}

The geology of the Thompson Falls 1:100,000 quadrangle, Idaho was compiled by Reed S. Lewis in 1997 onto a 1:100,000-scale greenline mylar of the topographic base map for input into a geographic information system (GIS). The resulting digital geologic map GIS can be queried in many ways to produce a variety of geologic maps. Digital base map data files (topography, roads, towns, rivers and lakes, etc.) are not included: they may be obtained from a variety of commercial and government sources. This database is not meant to be used or displayed at any scale larger than 1:100,000 (e.g., $1: 62,500$ or $1: 24,000)$.

The map area is located in north Idaho (Fig. 1). This open-file report describes the geologic map units, the methods used to convert the geologic map data into a digital format, the Arc/Info GIS file structures and relationships, and explains how to download the digital files from the U.S. Geological Survey public access World Wide Web site on the Internet.

We thank Steve Box, Tom Frost, and Brian White for their technical reviews and Nancy Shock for a digital review. 


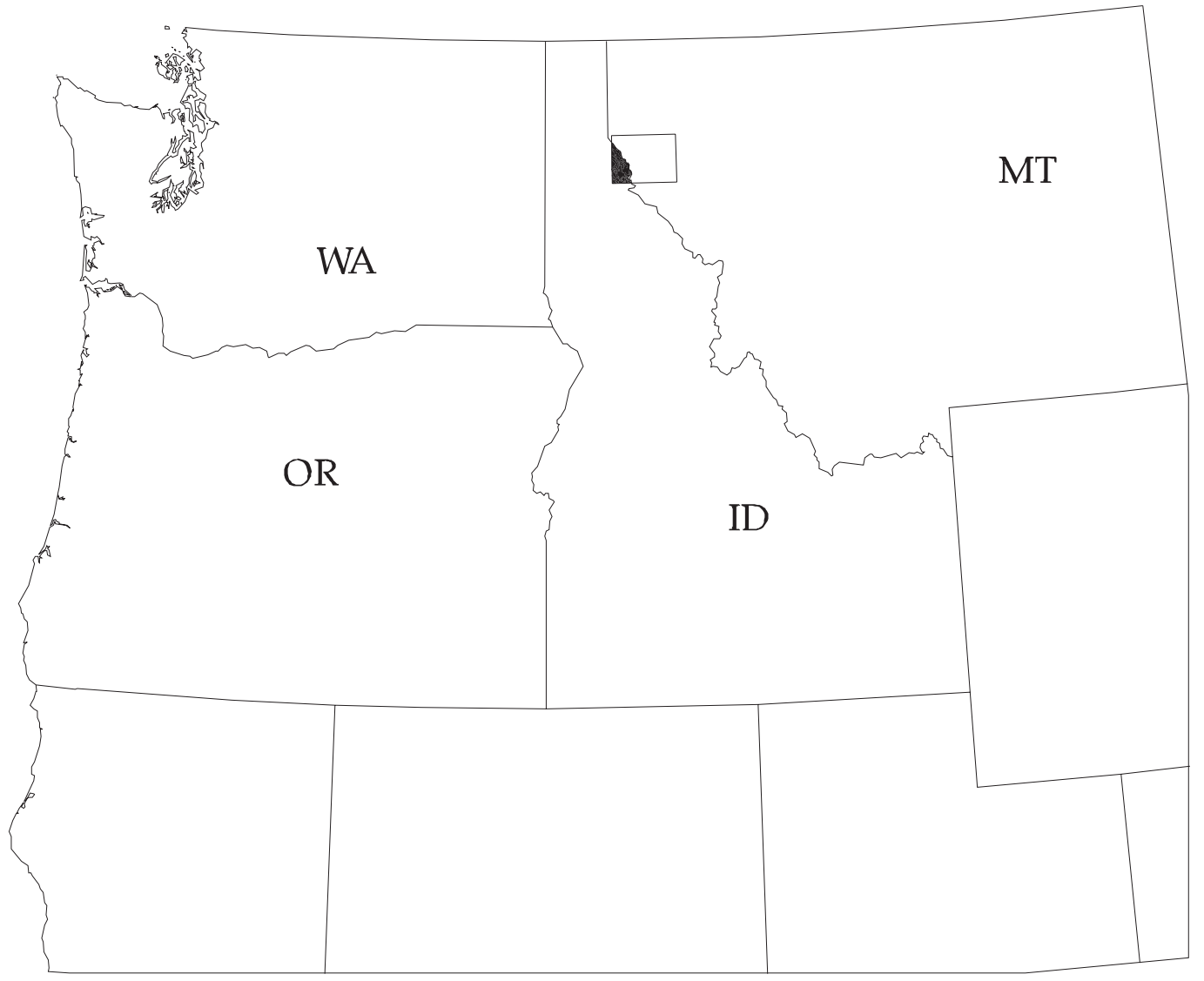

Figure 1. Index map showing the geographic extent of the mapped area (black fill) and the Thompson Falls quadrangle with respect to the Pacific Northwest. 


\section{Description of Map Units}

The geologic map was compiled primarily from Griggs (unpublished field maps dated 1961-1969, 1973), Harrison and others (1986), Hobbs and others (1965), Hosterman (1956) and Ransome and Calkins (1908) (see Fig. 2, areas 1-6). Additional map sources used were Gibson and others (1941), Schalck (1989), Shenon (1938), Umpleby and Jones (1923), and B.G. White (written commun., 1997) (see Fig. 2, areas A-E).

Qa ALLUVIAL DEPOSITS (HOLOCENE)--Stream deposits in modern drainages.

Qg GLACIAL DEPOSITS (QUATERNARY)--Poorly sorted and poorly stratified, unconsolidated deposits principally of glacial origin. Includes till in lateral and ground moraines as well as outwash and minor modern stream alluvium.

Tsm SEDIMENT (MIOCENE)--Unconsolidated, poorly sorted, fluvial sediment 70 to $330 \mathrm{~m}$ above the present stream levels. Ranges in size from clay to boulders and is derived from local sources (Hosterman, 1956).

Kms MONZONITE AND SYENITE (CRETACEOUS)--Small stocks of hornblende monzonite, porphyritic hornblende monzonite, alkali-feldspar syenite, and pyroxene syenite (Schlack, 1989). Age determinations have yielded conflicting dates, but emplacement ages of about 100 Ma are likely (Marvin and others, 1984; Schlack, 1989).

Ysp STRIPED PEAK FORMATION (MIDDLE PROTEROZOIC)--Interbedded quartzite and argillite with some arenaceous dolomitic beds; usually thinly bedded (Hobbs and others, 1965). Colors range from purplish gray and very pale pink to gray and green. Mud cracks and ripple marks common.

Ywu WALLACE FORMATION, UPPER MEMBER (MIDDLE PROTEROZOIC)-Predominantly thinly laminated medium- to dark-gray argillite; some interbedded light-gray quartzite and arenaceous dolomite (Hobbs and others, 1965).

Ywml WALLACE FORMATION, MIDDLE AND LOWER MEMBERS, UNDIVIDED (MIDDLE PROTEROZOIC)--Light-gray dolomitic and calcareous quartzite interbedded with medium- to dark-gray argillite (Hobbs and others, 1965). Some impure dolomite beds near top. Ripple marks, small scale crossbedding, and molar-tooth and ovoid structures in some layers. Mapped as Ywl by Hobbs and others (1965). 


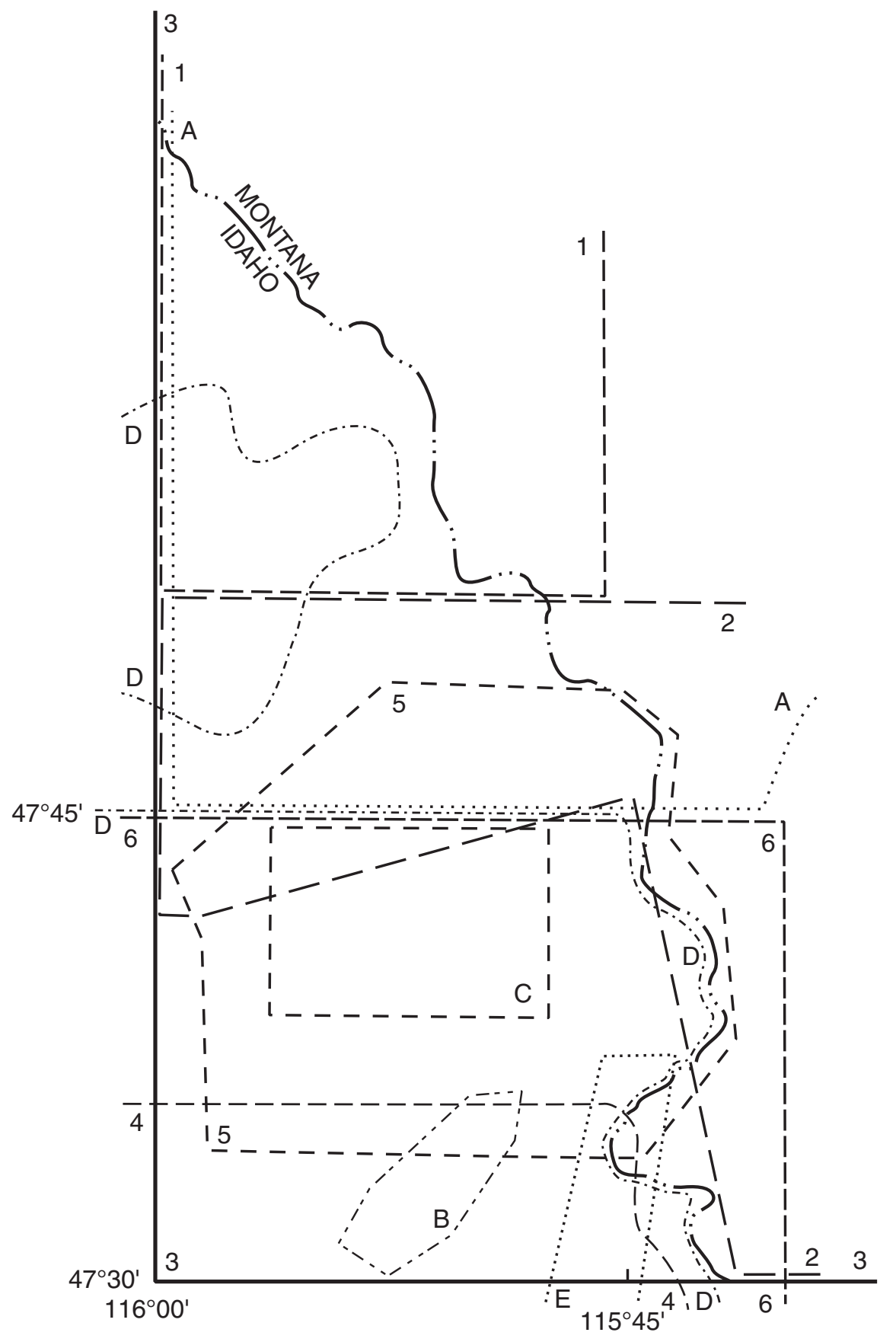

\section{Primary sources:}

1. Griggs, unpub. mapping a.

2. Griggs, unpub. mapping b.

3. Harrison and others, 1986

4. Hobbs and others, 1965

5. Hosterman, 1956

6. Ransome and Calkins, 1908

\section{Additional Map References}

A. Gibson and others, 1941

B. Schalck, 1989.

C. Shenon, 1938.

D. Umpleby and Jones, 1923

E. White, B.G., unpub mapping.

Figure 2. Location map showing primary sources of compilation data (areas 1-6) and additional map references (A-E). 
Ysr ST. REGIS FORMATION (MIDDLE PROTEROZOIC)--Thick-bedded impure to pure quartzite at base, grading upward to interbedded and interlaminated impure quartzite and argillite that comprise bulk of formation (Hobbs and others, 1965). Characteristically thin bedded and many layers laminated. Predominantly purplish red and grayish red; argillite is darker. Some carbonate-bearing beds, mostly in upper part. Ripple marks, mud cracks, and mud-chip breccia in some layers.

Yr REVETT FORMATION (MIDDLE PROTEROZOIC)--Thick-bedded white to light-gray quartzite containing interbedded impure and nearly pure quartzite in upper and lower parts, and a few widely spaced argillite partings (Hobbs and others, 1965). Crossbedded and laminated in part.

Ybk BURKE FORMATION (MIDDLE PROTEROZOIC)--Light- to greenish-gray fine-grained impure quartzite with lesser amounts of nearly white to light-gray nearly pure to pure quartzite (Hobbs and others, 1965). Beds predominantly 5 to $20 \mathrm{~cm}$ thick. Ripple marks and pseudoconglomerate are common.

Ypu PRICHARD FORMATION, UPPER MEMBER (MIDDLE PROTEROZOIC)-Light-gray to nearly white pure to impure quartzite interbedded with laminated argillite (Hobbs and others, 1965). Quartzite beds 5 to $45 \mathrm{~cm}$ thick. Ripple marks and graded bedding are common.

Ypl PRICHARD FORMATION, LOWER MEMBER (MIDDLE PROTEROZOIC)-Banded dark-gray argillite, laminated in part; weathers rusty red (Hosterman, 1956). 


\section{Data Sources, Processing, and Accuracy}

Lewis'greenline mylar inked with the geologic data was electronically scanned to create a raster digital image, converted to vector, polygon and point GIS layers, and minimally attributed by a contractor (Optronics Specialty Co., Inc., Northridge, CA). This initial product, with latitude and longitude registration tics digitized from the scanned image, was remitted to the U.S. Geological Survey in an Arc/Info EXPORT format in scanner units. The tic points were used to transform the digital files to calculated latitudelongitude points for a Universal Transverse Mercator (zone 11, with a -5,000,000 m yoffset) map projection. The RMS errors ${ }^{1}$ resulting from the file transformations were small (7.350 meters, see Appendix A). The digital files were then augmented with an interim geologic map data model (or data base), further attributed and edited, and then plotted and compared to the original greenline mylar of the geologic map to check for digitizing and attributing errors. All processing by the U.S. Geological Survey was done in Arc/Info version 7.1.1 installed on a Sun Ultra workstation.

The overall accuracy (with respect to the location of lines and points) of the digital geologic map (see Figs. 3 and 4 for pagesize versions) is probably no better than $+/-7$ meters. This digital database is not meant to be used or displayed at any scale larger than 1:100,000 (e.g., 1:62,500 or 1:24,000).

\footnotetext{
${ }^{1}$ The root mean square error (RMS error) describes the deviation between the tic locations in the input file and those in the output file. It is an indication of the quality of the derived transformation and is a measure of the quality of the original scanned materials. The transformation report of errors for each tic point is given in Appendix A.
} 
Qa - alluvial deposits (Holocene) Stream deposits in modern drainages.

Qg - glacial deposits (Quaternary) Poorly sorted and poorly stratified unconsolidated deposits principally of glacial origin. Includes till in lateral and ground moraines as well as outwash and minor modern stream alluvium.

Tsm - sediment (Miocene)

Unconsolidated, poorly sorted, fluvial sediment 70 to $330 \mathrm{~m}$ above the present stream levels. Ranges in size from clay to boulders and is derived from local sources (Hosterman, 1956).

Kms - monzonite and syenite (Cretaceous)

Small stocks of hornblende monzonite, porphyritic hornblende monzonite, alkall-feldspar syenite, and pyroxene syenite (Schlack, 1989). Age determinations have yielded conflicting dates, but emplacement ages of about $100 \mathrm{Ma}$ are likely (Marvin and others, 1984; Schlack, 1989).

\section{Ysp - Striped Peak Formation} (Middle Proterozoic)

Interbedded quartzite and argillite with some arenaceous dolomitic beds; usually thinly bedded (Hobbs and others, 1965). Colors range from purplish gray and very pale pink to gray and green. Mud cracks and ripple marks common.

Ywu - Wallace Formation, upper member (Middle Proterozoic) Predominantly thinly laminated mediumto dark-gray argillite; some interbedded light-gray quartzite and arenaceous dolomite (Hobbs and others, 1965).
Ywml - Wallace Formation, middle and lower members, undivided (Middle Proterozoic) Light-gray dolomitic and calcareous quartzite interbedded with mediumto dark-gray argillite (Hobbs and others, 1965). Some impure dolomite beds near top. Ripple marks small ccale crossbedding, and molar-tooth scale cross structures in some layers. Mapped as Ywl by Hobbs and others Mapped as Ywhby Hobbs and others (1965).

\section{Ysr - St. Regis Formation}

(Middle Proterozoic)

Thick-bedded impure to pure quartzite at base, grading upward to interbedded and interlaminated impure quartzite and argillite that comprise bulk of formation (Hobbs and others, 1965). Characteristically thin bedded and many layers laminated. Predominantly purplish red and grayish red;

argillite is darker. Some carbonatebearing beds, mostly in upper part.

Ripple marks, mud cracks, and mud-chip breccia in some layers.

Yr - Revett Formation (Middle Proterozoic)

Thick-bedded white to light-gray quartzite containing interbedded impure and nearly pure quartzite in upper and lower parts, and a few widely-spaced argillite partings (Hobbs and others. 1965). Crossbedded and laminated in part.

\section{Ybk - Burke Formation}

(Middle Proterozoic)

Light greenish-gray fine-grained impure quartzite with lesser amounts of nearly white to light-gray nearly pure to pure quartzite (Hobbs and others, 1965). Beds predominantly 5 to $20 \mathrm{~cm}$ thick.

Ripple marks and pseudoconglomerate are common.
Ypu - Prichard Formation, upper member (Middle Proterozoic) Light-gray to nearly white pure to impure quartzite interbedded with laminated argillite (Hobbs and others, 1965). Quartzite beds 5 to $45 \mathrm{~cm}$ thick. Ripple marks and graded bedding are common.

Ypl - Prichard Formation, lower member (Middle Proterozoic) Banded dark-gray argillite, laminated in part; weathers rusty red (Hosterman, 1956).

contact

fault

Figure 3. Explanation for the Simplified Digital Geologic Map of the Thompson Falls 1:100,000 quadrangle, Idaho 


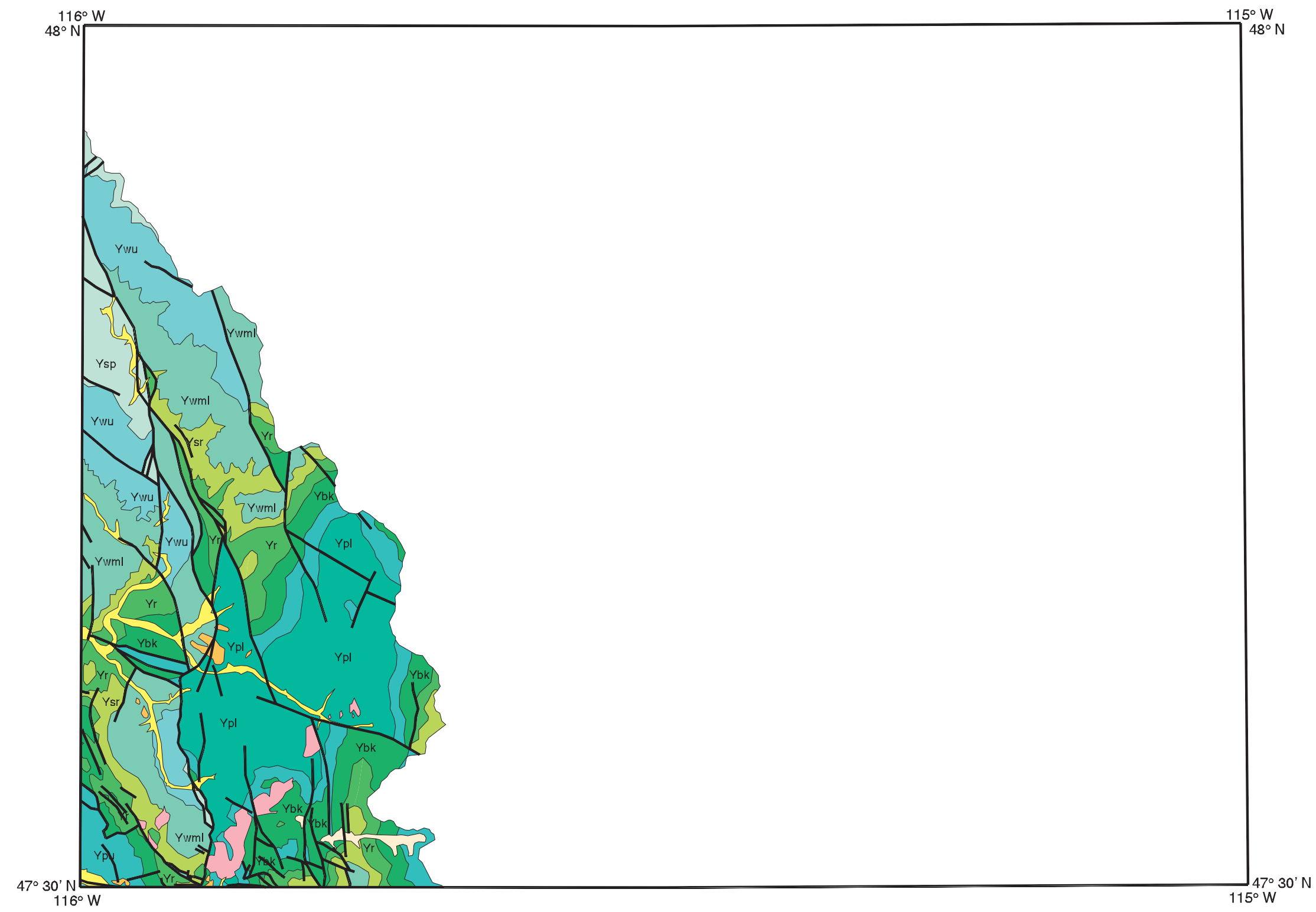

Figure 4. Simplified Digital Geologic Map of the Thompson Falls 1:100,000 quadrangle, Idaho 


\section{GIS Documentation}

The digital geologic map of the Thompson Falls 1:100,000 quadrangle, Idaho includes a geologic linework arc attribute table, TF100K.AAT, that relates to the TF100K.CON, TF100K.STR and TF100K.REF files; a rock unit polygon attribute table, TF100K.PAT, that relates to the TF100K.RU and TF100K.REF files; and a geologic map symbol point attribute table, TFPNT.PAT, that relates to the TFPNT.SYM and TFPNT.REF files (see Fig. 5). These data files are described below.

\section{Linear Features}

Descriptions of the items identifying linear features such as contacts, boundaries (e.g., lines of latitude and longitude, state boundaries) and structures in the arc (or line) attribute table, TF100K.AAT, are as follows:

\begin{tabular}{|l|l|l|l|}
\hline \multicolumn{2}{|l|}{ TF100K.AAT } \\
\hline $\begin{array}{l}\text { ITEM } \\
\text { NAME }\end{array}$ & $\begin{array}{l}\text { ITEM } \\
\text { TYPE }\end{array}$ & $\begin{array}{l}\text { ITEM } \\
\text { WIDTH }\end{array}$ & ATTRIBUTE DESCRIPTION \\
\hline linecode & integer & 3 & $\begin{array}{l}\text { Numeric code used to identify type of linear feature. } \\
\text { Linecodes < 100 are used for contacts and boundaries } \\
\text { which are described in the TF100K.CON file. } \\
\text { Linecodes > 100 and < 600 represent structural features } \\
\text { which are described in the TF100K.STR file. }\end{array}$ \\
\hline name & character & 30 & Name given to structural feature. \\
\hline source & integer & 4 & $\begin{array}{l}\text { Numeric code used to identify the data source for the } \\
\text { linear feature. Complete references for the sources are } \\
\text { listed in the TF100K.REF file. }\end{array}$ \\
\hline
\end{tabular}

Attribute descriptions for items in the contact (and boundary) look-up table, TF100K.CON (for use with the PLOTTER.LIN lineset), are as follows:

\begin{tabular}{|l|l|l|l|}
\hline \multicolumn{1}{|l|}{ TF100K.CON } \\
\hline $\begin{array}{l}\text { ITEM } \\
\text { NAME }\end{array}$ & $\begin{array}{l}\text { ITEM } \\
\text { TYPE }\end{array}$ & $\begin{array}{l}\text { ITEM } \\
\text { WIDTH }\end{array}$ & ATTRIBUTE DESCRIPTION \\
\hline linecode & integer & 3 & $\begin{array}{l}\text { Numeric code (a value < 100) used to identify type of } \\
\text { contact or boundary. (This item also occurs in } \\
\text { TF100K.AAT.) }\end{array}$ \\
\hline symbol & integer & 3 & $\begin{array}{l}\text { Line symbol number used by Arc/Info to plot line. } \\
\text { (Symbol numbers refer to the PLOTTER.LIN lineset.) }\end{array}$ \\
\hline type & character & 10 & $\begin{array}{l}\text { Major type of line, e.g., contact, state boundaries, lines of } \\
\text { latitude and longitude used for neatlines. }\end{array}$ \\
\hline modifier & character & 20 & $\begin{array}{l}\text { Line type modifier, i.e., approximate, concealed, } \\
\text { gradational. No entry implies 'known.' }\end{array}$ \\
\hline certainty & character & 15 & $\begin{array}{l}\text { Degree of certainty of contact or boundary, i.e., inferred, } \\
\text { uncertain. No entry implies 'certain.' }\end{array}$ \\
\hline desc & character & 100 & $\begin{array}{l}\text { Written description or explanation of contact or } \\
\text { boundary. }\end{array}$ \\
\hline
\end{tabular}


Arc attribute table and related look-up tables:

\begin{tabular}{|l|}
\hline tf100k.aat \\
\hline linecode \\
\hline name \\
\hline source \\
\hline tf100k.con \\
\hline linecode \\
\hline symbol \\
\hline type \\
\hline modifier \\
\hline certainty \\
\hline desc \\
\hline \\
\hline tf100k.str \\
\hline linecode \\
\hline symbol \\
\hline type \\
\hline horizontal \\
\hline vertical \\
\hline fold \\
\hline plunge \\
\hline accuracy \\
\hline certainty \\
\hline desc \\
\hline tf100k.ref: \\
\hline source \\
\hline scale \\
\hline authors \\
\hline year \\
\hline
\end{tabular} \mid

Polygon attribute table and related look-up tables:

\begin{tabular}{|l|l|}
\hline tf100k .pat \\
\hline unit \\
\hline source \\
\hline label \\
\hline desc \\
\hline tf100k.ru \\
\hline unit \\
\hline label \\
\hline symbol \\
\hline name \\
\hline ss \\
\hline lith \\
\hline desc \\
\hline minage \\
\hline maxage \\
\hline mindate \\
\hline maxdate \\
\hline \\
\hline tf100k.ref: \\
\hline source \\
\hline scale \\
\hline authors \\
\hline year \\
\hline reference \\
\hline
\end{tabular}

Point attribute table and related look-up tables:

\begin{tabular}{|l|l|}
\hline tfpnt .pat \\
\hline pttype \\
\hline symbol \\
\hline strike \\
\hline dip \\
\hline calcang \\
\hline sym\$angle \\
\hline source \\
\hline \\
\hline tfpnt .sym \\
\hline pttype \\
\hline symbol \\
\hline desc \\
\hline tfpnt .ref \\
\hline source \\
\hline scale \\
\hline authors \\
\hline year \\
\hline reference \\
\hline
\end{tabular}

Figure 5: Relationships between feature attribute tables and look-up tables. 
Attribute descriptions for items in the structure look-up table, TF100K.STR [for use with the GEOLOGY.LIN lineset (Fitzgibbon and Wentworth, 1991)], are as follows:

\begin{tabular}{|c|c|c|c|}
\hline \multicolumn{4}{|c|}{ TF100K.STR } \\
\hline $\begin{array}{l}\text { ITEM } \\
\text { NAME }\end{array}$ & $\begin{array}{l}\text { ITEM } \\
\text { TYPE }\end{array}$ & $\begin{array}{l}\text { ITEM } \\
\text { WIDTH }\end{array}$ & ATTRIBUTE DESCRIPTION \\
\hline linecode & integer & 3 & $\begin{array}{l}\text { Numeric code (a value }>100 \text { and }<600) \text { used to identify } \\
\text { type of structural feature. (This item also occurs in } \\
\text { TF100K.AAT.) }\end{array}$ \\
\hline symbol & integer & 3 & $\begin{array}{l}\text { Line symbol number used by Arc/Info to plot line. } \\
\text { (Symbol numbers refer to the GEOLOGY.LIN lineset } \\
\text { (Fitzgibbon and Wentworth, 1991).) }\end{array}$ \\
\hline type & character & 10 & Major type of structure, i.e., fault, fracture, fold, other. \\
\hline horizontal & character & 20 & $\begin{array}{l}\text { Type of horizontal fault movement, e.g., left-lateral, } \\
\text { right-lateral. No entry implies 'unknown.' }\end{array}$ \\
\hline vertical & character & 20 & $\begin{array}{l}\text { Type of vertical fault movement, e.g., normal. No entry } \\
\text { implies 'unknown.' }\end{array}$ \\
\hline fold & character & 15 & Type of fold, e.g., anticline, syncline. \\
\hline plunge & character & 15 & $\begin{array}{l}\text { Type of plunge on fold, i.e., horizontal, plunging, } \\
\text { plunging in, plunging out. }\end{array}$ \\
\hline accuracy & character & 15 & $\begin{array}{l}\text { Line type modifier indicating degree of accuracy, i.e., } \\
\text { approximately located, concealed, gradational. No entry } \\
\text { implies 'known.' }\end{array}$ \\
\hline certainty & character & 15 & $\begin{array}{l}\text { Degree of certainty of contact or boundary, i.e., inferred, } \\
\text { uncertain. No entry implies 'certain.' }\end{array}$ \\
\hline desc & character & 100 & Written description or explanation of structural feature. \\
\hline
\end{tabular}

\section{Areal Features}

Descriptions of the items identifying geologic units in the polygon attribute table, TF100K.PAT, are as follows:

\begin{tabular}{|l|l|l|l|}
\hline \multicolumn{2}{|l|}{ TF100K.PAT } \\
NAMM & $\begin{array}{l}\text { ITEM } \\
\text { TYPE }\end{array}$ & $\begin{array}{l}\text { ITEM } \\
\text { WIDTH }\end{array}$ & ATTRIBUTE DESCRIPTION \\
\hline unit & integer & 4 & $\begin{array}{l}\text { Numeric code used to identify the rock unit which is } \\
\text { described in the TF100K.RU look-up table. (This item } \\
\text { also occurs in TF100K.RU.) }\end{array}$ \\
\hline source & integer & 4 & $\begin{array}{l}\text { Numeric code used to identify the data source for the } \\
\text { rock unit. Complete references for the sources are listed } \\
\text { in the TF100K.REF file. }\end{array}$ \\
\hline label & character & 10 & $\begin{array}{l}\text { Rock unit label (abbreviation) used to label unit on map. } \\
\text { (This item was joined from the tf100k.ru look-up table.) }\end{array}$ \\
\hline desc & character & 100 & $\begin{array}{l}\text { Formal or informal unit name. } \\
\text { (This item was joined from the tf100k.ru look-up table.) }\end{array}$ \\
\hline
\end{tabular}


Attribute descriptions for items in the lithology (rock unit) look-up table, TF100K.RU (for use with the CALCOMP1.SHD shadeset), are as follows:

\begin{tabular}{|c|c|c|c|}
\hline \multicolumn{4}{|c|}{ TF100K.RU } \\
\hline $\begin{array}{l}\text { ITEM } \\
\text { NAME }\end{array}$ & $\begin{array}{l}\text { ITEM } \\
\text { TYPE }\end{array}$ & $\begin{array}{l}\text { ITEM } \\
\text { WIDTH }\end{array}$ & ATTRIBUTE DESCRIPTION \\
\hline unit & integer & 4 & $\begin{array}{l}\text { Numeric code used to identify rock unit. (This item also } \\
\text { occurs in TF100K.PAT.) }\end{array}$ \\
\hline label & character & 10 & Rock unit label (abbreviation) used to label unit on map. \\
\hline Symbol & integer & 3 & $\begin{array}{l}\text { Shadeset symbol number used by Arc/Info to plot a } \\
\text { filled/shaded polygon. (The symbol numbers used in this } \\
\text { file refer to the CALCOMP1.SHD shadeset.) }\end{array}$ \\
\hline name & character & 7 & $\begin{array}{l}\text { The prefix portion of the rock unit label that does not } \\
\text { include subscripts. (If subscripting is not used in the } \\
\text { original unit label, then the 'name' entry is the same as the } \\
\text { 'label' entry.) }\end{array}$ \\
\hline SS & character & 3 & $\begin{array}{l}\text { The suffix portion of the rock unit label that includes } \\
\text { subscripts. }\end{array}$ \\
\hline lith & character & 20 & $\begin{array}{l}\text { Major type of lithostratigraphic unit, i.e., unconsolidated } \\
\text { sediments, sedimentary rocks, metasedimentary rocks, } \\
\text { intrusive rocks, extrusive rocks, metamorphic rocks, } \\
\text { water, ice. }\end{array}$ \\
\hline desc & character & 100 & Formal or informal unit name \\
\hline minage & character & 7 & $\begin{array}{l}\text { Minimum stratigraphic age of lithologic unit, i.e., CRET, } \\
\text { TERT, PCY. }\end{array}$ \\
\hline maxage & character & 7 & Maximum stratigraphic age of lithologic unit \\
\hline mindate & integer & 4 & $\begin{array}{l}\text { Minimum radiometric age (in millions of years) if } \\
\text { determined. }\end{array}$ \\
\hline maxdate & integer & 4 & $\begin{array}{l}\text { Maximum radiometric age (in millions of years) if } \\
\text { determined. }\end{array}$ \\
\hline
\end{tabular}




\section{Point Features}

Descriptions of the items identifying geologic map symbols are given in the point attribute table, TFPNT.PAT, which is defined as follows:

\begin{tabular}{|l|l|l|l|}
\hline TFPNT.PAT & ITEM & $\begin{array}{l}\text { ITEM } \\
\text { TYPE }\end{array}$ & ATTRIBUTE DESCRIPTION \\
\hline ITEM NAME & character & 32 & $\begin{array}{l}\text { Type of point symbol, e.g., strike and dip of inclined } \\
\text { bedding. (This item also occurs in the TFPNT.SYM } \\
\text { file.) }\end{array}$ \\
\hline symbol & integer & 3 & $\begin{array}{l}\text { Marker symbol number used by Arc/Info to identify } \\
\text { type of structural map symbol. Symbol numbers } \\
\text { refer to the GEOSCAMP2.MRK markerset } \\
\text { (Matti and others, 1997). (This item also } \\
\text { occurs in the TFPNT.SYM file.) }\end{array}$ \\
\hline strike & integer & 3 & $\begin{array}{l}\text { Strike of bedding. Strike is an azimuthal angle } \\
\text { (measured in degrees from 0 to 360 in a clockwise } \\
\text { direction from North). }\end{array}$ \\
\hline dip & integer & 3 & $\begin{array}{l}\text { Dip of bedding. This value is an angle measured (in } \\
\text { degrees from 0 to 90) down from the horizontal; thus } \\
\text { a horizontal dip is 0 degrees and a vertical dip is 90 } \\
\text { degrees. }\end{array}$ \\
\hline calcang & integer & 4 & $\begin{array}{l}\text { An interim value used to calculate sym\$angle. The } \\
\text { structural map symbol in the GEOSCAMP2.MRK } \\
\text { markerset (Matti and others, 1997) had to } \\
\text { be rotated to achieve its proper map orientation. } \\
\text { For the strike and dip symbols, calcang = strike - } \\
\text { 270. }\end{array}$ \\
\hline sym\$angle & integer & 4 & $\begin{array}{l}\text { The angle used to mathematically rotate the map } \\
\text { point symbol to its proper orientation on the map. } \\
\text { This item was set equal to the pseudoitem '\$angle' } \\
\text { (calc sym\$angle = \$angle). }\end{array}$ \\
\hline integer & 4 & $\begin{array}{l}\text { Numeric code used to identify the data source for the } \\
\text { geologic map symbol. Complete references for the } \\
\text { sources are listed in the TFPNT.REF file. }\end{array}$ \\
\hline
\end{tabular}


Attribute descriptions for items in the geologic map symbols look-up table, TFPNT.SYM, [for use with the GEOSCAMP2.MRK markerset (Matti and others, 1997)], are as follows:

\begin{tabular}{|l|l|l|l|}
\hline \multicolumn{2}{|l|}{ TFPNT.SYM } \\
\hline $\begin{array}{l}\text { ITEM } \\
\text { NAME }\end{array}$ & $\begin{array}{l}\text { ITEM } \\
\text { TYPE }\end{array}$ & $\begin{array}{l}\text { ITEM } \\
\text { WIDTH }\end{array}$ & ATTRIBUTE DESCRIPTION \\
\hline pttype & character & 32 & $\begin{array}{l}\text { Type of point symbol, e.g., strike and dip of inclined } \\
\text { bedding, strike and dip of inclined cleavage. (This item } \\
\text { also occurs in the TFPNT.PAT file.) }\end{array}$ \\
\hline symbol & integer & 3 & $\begin{array}{l}\text { Marker symbol number used by Arc/Info to identify type } \\
\text { of geologic map symbol. Symbol numbers refer to the } \\
\text { GEOSCAMP2.MRK markerset (Matti and } \\
\text { others, 1997). }\end{array}$ \\
\hline desc & character & 250 & Written description or explanation of map symbol. \\
\hline
\end{tabular}

\section{Source Attributes}

Descriptive source or reference information for the TF100K and TFPNT Arc/Info coverage files is stored in the TF100K.REF and TFPNT.REF files respectively. Attribute descriptions for items in the TF100K.REF and TFPNT.REF data source files are as follows:

\begin{tabular}{|l|l|l|l|}
\hline \multicolumn{2}{|l|}{ TF100K.REF / TFPNT.REF } \\
\hline $\begin{array}{l}\text { ITEM } \\
\text { NAME }\end{array}$ & $\begin{array}{l}\text { ITEM } \\
\text { TYPE }\end{array}$ & $\begin{array}{l}\text { ITEM } \\
\text { WIDTH }\end{array}$ & ATTRIBUTE DESCRIPTION \\
\hline Source & integer & 4 & $\begin{array}{l}\text { Numeric code used to identify the data source. (This item } \\
\text { also occurs in the TF100K.AAT, TF100K.PAT, and } \\
\text { TFPNT.PAT files.) }\end{array}$ \\
\hline scale & integer & 10 & $\begin{array}{l}\text { Scale of source map. (This value is the denominator of } \\
\text { the proportional fraction that identifies the scale of the } \\
\text { map that was digitized or scanned to produce the digital } \\
\text { map.) }\end{array}$ \\
\hline authors & character & 100 & $\begin{array}{l}\text { Author(s) or compiler(s) of source map entered as last } \\
\text { name, first name or initial, and middle initial. }\end{array}$ \\
\hline year & integer & 4 & Source (map) publication date \\
\hline reference & character & 250 & Remainder of reference in USGS reference format. \\
\hline
\end{tabular}




\section{Obtaining Digital Data}

The complete digital version of the geologic map is available in Arc/Info interchange (or 'EXPORT') format with associated data files. These data and map images are maintained in a Universal Transverse Mercator (UTM) map projection:

$\begin{array}{ll}\text { Projection: } & \text { UTM } \\ \text { Zone: } & 11 \\ \text { Y-offset (false northing): } & -5,000,000 \text { meters } \\ \text { Units: } & \text { meters }\end{array}$

To obtain copies of the digital data, do one of the following:

1. Download the digital files from the USGS public access World Wide Web site on the Internet: URL = http://wrgis.wr.usgs.gov/open-file/of99-438/

or

2. Anonymous FTP from wrgis.wr.usgs.gov, in the directory pub/open-file/of99-438/

The Internet sites contain the digital geologic map of part of the Thompson Falls 1:100,000 quadrangle, Idaho both in Arc/Info interchange-format files (tf 100k.e00 and tf100k.e00) and as an HPGL2 plot file (tf100k.hp) of the map area, as well as the associated data files and Arc/Info macro program which is used to plot the map at a scale of 1:100,000.

To manipulate this data in a geographic information system (GIS), you must have a GIS that is capable of reading Arc/Info interchange-format files.

\section{Obtaining Paper Maps}

Paper copies of the digital geologic map are not available from the USGS. However, with access to the Internet and access to a large-format color plotter that can interpret HPGL2 (Hewlett-Packard Graphics Language), a 1:100,000-scale paper copy of the map can be made, as follows:

1. Download the plot file of the map, tf100k.hp, from the USGS public access World Wide Web site on the Internet using the URL = http://wrgis.wr.usgs.gov/open-file/of99-438 or

2. Anonymous FTP the plot file, tf100k.hp, from: wrgis.wr.usgs.gov, in the directory: pub/open-file/of99-438/

3. This file can be plotted by any large-format color plotter that can interpret HPGL2. The finished plot is about 29 inches by 39 inches.

Paper copies of the map can also be created by obtaining the digital files as described above and then creating a plot file in a GIS, using the Arc/Info macro language (AML) program, tf100k.aml, included in the data package. 


\section{References Cited}

Fitzgibbon, Todd T. and Wentworth, Carl M., 1991, ALACART user interface executable AML code and demonstration maps: U.S. Geological Survey Open-File Report 91-587A (as updated October 17, 1996 for version 3.1), URL = http://wrgis.wr.usgs.gov/docs/software/software.html

Gibson, Russell, Jenks, W. F., and Campbell, Ian, 1941, Stratigraphy of the Belt series in Libby and Trout Creek quadrangles, northwestern Montana and northern Idaho: Geological Society of America Bulletin, v. 52, no. 3, p. 363-379, scale 1:180,000 (approx.).

Griggs, A.B., 1961-1969 and 1973, unpublished geologic maps of the Bloom Peak 7.5-, Burke 15-, Cooper Gulch 15-, Gem Peak 7.5-, Noxon 7.5- and Taylor Peak 7.5minute quadrangles, Idaho: U.S. Geological Survey Field Records Library, Denver, CO, scale 1:62,500.

Harrison, J.E., Griggs, A.B. and Wells, J.D., 1986, Geologic and structure maps of the Wallace 1- by 2-degree quadrangle, Montana and Idaho: U.S. Geological Survey Miscellaneous Investigations Series Map I-1509A, 2 plates, scale 1:250,000.

Hobbs, S.W., Griggs, A.B., Wallace, R.E. and Campbell, A.B., 1965, Geology of the Coeur d'Alene district, Shoshone County, Idaho: U.S. Geological Survey Professional Paper 478, 139 p., 10 plates, scale 1:24,000.

Hosterman, J.W., 1956, Geology of the Murray area, Shoshone County, Idaho: U.S. Geological Survey Bulletin 1027-P, p. 725-748, scale 1:62,000.

Marvin, R.F., Zartman, R.E., Obradovich, J.D. and Harrison, J.E., 1984, Geochronometric and lead isotope data on samples from the Wallace 1- by 2-degree quadrangle, Montana and Idaho: U.S. Geological Survey Miscellaneous Field Studies Map MF-1354-G, scale 1:250,000.

Matti, J.C., Miller, F.K., Powell, R.E., Kennedy, S.A., Bunyapanasarn, T.P., Koukladas, C., Hauser, R.M., and Cossette, P.M., 1997, Geologic-point attributes for digital geologic-map data bases produced by the Southern California Areal Mapping Project (SCAMP): U.S. Geological Survey Open-File Report 97-859, 7 p.

Ransome, F.L. and Calkins, F.C., 1908, The geology and ore deposits of the Coeur d'Alene district, Idaho: U.S. Geological Survey Professional Paper 62, 203 p., scale 1:62,500.

Schalck, D.K., 1989, The geology and alteration of the Gem stocks, Shoshone County, Idaho: in V. E. Chamberlain, R. M. Breckenridge, and Bill Bonnichsen (editors), Guidebook to the geology of northern and western Idaho and surrounding area: Idaho Geological Survey Bulletin 28, p. 125-135.

Shenon, P.J., 1938, Geology and ore deposits near Murray, Idaho: Idaho Bureau of Mines and Geology Pamphlet 47, 44 p.

Umpleby, J.B. and Jones, E.L., Jr., 1923, Geology and ore deposits of Shoshone County, Idaho: U. S. Geological Survey Bulletin 732, 156 p., scale 1:250,000.

U.S. Geological Survey, 1993, 1:100,000-scale digital line graph (DLG) data hydrography and transportation, Area 13 - Northwestern states: U.S. Geological Survey, US GeoData (optional format), CD-ROM. 


\section{Appendix A - Transformation report for Thompson Falls GIS}

Three Arc/Info files were remitted to the USGS from the contractor. Each of the three files had to be transformed to a UTM map projection (zone 11, y-shift $=-5,000,000$ meters). The errors for each latitude and longitude tic used in the transformation were the same for each of the three transformed files and are given below. The report identifies a root mean square (RMS) error of 7.350 meters.

Arc: transform tfgeo1 tfgeo 2 affine

Transforming coordinates for coverage tfgeo1

Scale $(X, Y)=(2539.930,2539.720)$ Skew $($ degrees $)=(0.003)$

Rotation $($ degrees $)=(1.115)$ Translation $=(573977.416,258440.517)$

RMS Error (input,output) $=(0.003,7.350)$

Affine $X=A x+B y+C$

$$
\mathrm{Y}=\mathrm{Dx}+\mathrm{Ey}+\mathrm{F}
$$

$$
\begin{array}{lcllll}
\mathrm{A}= & 2539.449 & \mathrm{~B}= & -49.289 & \mathrm{C}= & 573977.416 \\
\mathrm{D}= & 49.422 \mathrm{E}= & 2539.242 & \mathrm{~F}= & 258440.517
\end{array}
$$

\begin{tabular}{|c|c|c|c|c|}
\hline & output $\mathrm{x}$ & output y & $\mathrm{X}$ error & y error \\
\hline 451 & 0.548 & 0.992 & & \\
\hline & 575315.438 & 260995.594 & 4.232 & -9.184 \\
\hline 382 & 0.614 & 11.936 & & \\
\hline & 574957.188 & 288779.781 & -9.395 & -0.235 \\
\hline 313 & 0.686 & 22.876 & & \\
\hline & 574597.438 & 316565.156 & -5.935 & -3.356 \\
\hline 452 & 7.962 & 0.962 & & \\
\hline & 594144.062 & 261268.203 & 5.379 & 8.662 \\
\hline 453 & 15.372 & 0.946 & & \\
\hline & 612972.562 & 261601.406 & -5.338 & 0.666 \\
\hline 383 & 8.000 & 11.902 & & \\
\hline & 593696.188 & 289052.156 & 9.488 & 5.726 \\
\hline 314 & 8.032 & 22.844 & & \\
\hline & 593246.562 & 316837.312 & 1.213 & 5.522 \\
\hline 384 & 15.372 & 11.886 & & \\
\hline & 612435.062 & 289385.094 & -7.696 & -3.477 \\
\hline 315 & 15.378 & 22.830 & & \\
\hline & 611895.438 & 317169.938 & 8.105 & 1.421 \\
\hline 454 & 22.790 & 0.954 & & \\
\hline & 631800.875 & 261995.219 & 3.318 & -5.635 \\
\hline 385 & 22.756 & 11.900 & & \\
\hline
\end{tabular}


Appendix A

$\begin{array}{ccccc} & 631173.750 & 289778.625 & 4.419 & 3.447 \\ 316 & 22.718 & 22.840 & & \\ & 630544.125 & 317563.125 & -1.855 & -3.577 \\ 455 & 30.202 & 0.992 & & \\ & 650628.938 & 262449.656 & -3.689 & 2.694 \\ 386 & 30.132 & 11.934 & & \\ & 649912.188 & 290232.688 & -4.667 & 0.102 \\ 317 & 30.064 & 22.876 & & \\ & 649192.562 & 318016.781 & 2.420 & -2.777\end{array}$




\section{Appendix B - List of digital files in the Thompson Falls GIS}

--Use the '00import.aml' to IMPORT all of the *.E00 files for use in Arc/Info.

--Use the Arc/Info 'DRAW' command to plot the *.GRA file to your screen. (Make sure the display is set with the Arc/Info 'DISPLAY' command.)

--Use the Arc/Info 'HPGL2' command to create HPGL2 files from the *.GRA file.

--Use the UNIX 'lpr -P<plotter_name> tf100k.hp' command to send the tf100k.hp file to a large-format color plotter that can interpret Hewlett-Packard Graphics Language.

--To re-create the *.GRA file, open the ArcPlot module, enter 'display 1040', enter a new filename for the graphics file, enter '\&run tf100k' (and at the ARC prompt, enter 'display 9999 3' and 'draw <new filename> to draw the GRA file to your screen).

\section{Primary Arc/Info interchange-format} files (tf*.e00) for the digital geology:

- tf100k.e00

- tfpnt.e00

\section{Plot files}

Plot files in Arc/Info graphics (*.gra) and HPGL2 map plot (*.hp) formats for the geologic map plate:

- tf100k.gra /.hp

\section{Additional Arc/Info interchange-} format files (*.e00) necessary to recreate the geologic map plate:

- calcomp1.shd.e00 - shadeset

- fnt038.e00 - font 38

- fnt040.e00 - font 40

- geoscamp2.mrk.e00 - markerset

- tfallsu $11^{1}$.e00 - exterior boundary of the Thompson Falls quadrangle

\section{AML, graphics, key, lineset and text files necessary to re-create the geologic map plate: \\ - scale2a.aml - plots scale bar on plate \\ - tf100k.aml - program that creates a graphics file of the geologic map of the Thompson Falls quadrangle, Idaho.}

\footnotetext{
1 an 'u11' suffix indicates UTM, zone 11 map projection with $\mathrm{y}$-shift $=5,000,000$ meters.
}

- index_tf.gra - index map graphic displayed on map plate (showing location of the Thompson Falls quadrangle with respect to the Pacific Northwest).

- tf_line.key - lineset symbol values and descriptive text for lines on the map plate

- tf_pol.key - shadeset symbol values and descriptive text for geologic map units on the map plate

- tf_sym.key - markerset symbol values and descriptive text for map symbols (markers) on the map plate

- geology.lin - lineset

- geo.prj - a text file used to identify real-world (geographic) coordinates for use in adding latitude and longitude notation around the margins of the map quadrangle

- u11.prj - a text file to identify UTM, zone 11 map projection - for use in adding latitude and longitude notation around the margins of the map quadrangle

- tfcrd.txt - text file listing map credits on the map plates

- tfdisc.txt - disclaimer statement text file

- $\quad$ ffref.txt - text file listing map references on the map plates 


\section{Appendix C - Arc/Info Macro Language program (tf100k.aml) used to plot the geologic map of the Thompson Falls quadrangle}

\author{
/* tf100k.aml, 11/24/98, pd \\ $/ * * * * * * * * * * * * * * * * * * * * * * * *$ \\ /* This Arc/Info Macro Language (AML) \\ program will plot the geologic map plate for the \\ Thompson Falls, ID 1:100,000-scale quadrangle. \\ /* To run this AML: \\ /* 1. Type 'ap' at the 'Arc:' prompt to enter the \\ ArcPlot module, \\ /* 2. Type 'display 1040' at the 'Arcplot:' \\ prompt to create a GRA file, \\ $/ * 3$. Enter a filename of your own choosing \\ at the 'Enter ARC/INFO Graphics filename :' \\ prompt for the GRA to be created, \\ /* 4. Type '\&run tf $100 \mathrm{k}$ ' at the 'Arc:' prompt \\ to start the program, \\ /* 5. Enter 'quit' to exit the ArcPlot module \\ /* 6. At the 'Arc:' prompt, type 'display 9999 \\ 3 ' to set the display window \\ /* 7. At the next 'Arc:' prompt, enter 'draw \\ <quadname>' -- there is no need to use the GRA \\ extension. \\ /* 8. Run the Arc/Info HPGL2 command to \\ convert the GRA file to an HPGL2 file, i.e., \\ hpgl2 tf100k tf100k.hp \# 1.0 opaque \# 0 \# \# \# \\ cal.dat \\ /* 9. Execute the UNIX 'lpr' command to \\ print the 1:100,000-scale geologic map plot on \\ your plotter, i.e., lpr -Ppicasso tf100k.hp \\ /************************** \\ clear \\ clearselect
}

pagesize 40.529 .0

pageunits inches

mapunits meters

mapscale 100000

mapposition 110.02 .5

mapangle -1.0

\&set cover1 tf100k

\&set pntcover tfpnt

\&set quad tfallsu11

\&set key1 tf_pol.key

\&set key2 tf_line.key

\&set key3 tf_sym.key

\&s credits tfcrd.txt \&s refs tfref.txt

\&s disclaimer tfdisc.txt

/* --> where 'cover1' contains contacts and structures and rock units; 'pntcover' contains structural symbols; and 'quad' is the quadrangle boundary.

mape \%quad $\%$

maplimits 0.02 .43227

/*draw outside box

linesymbol 9

linecolor 1

box 0.50 .53928 .5

textquality proportional

textfont 94021

linedelete all

lineset plotter

lineset carto

/* cut marks

markerset plotter

markersymbol 1

markersize 0.1

marker 00

marker 029

marker 39.50

marker 39.529

markerset water

\&label shadepolys

/* color polygons for geologic rock units

shadedelete all

shadeset calcomp1

polygonshade \%cover $1 \%$ unit \%cover $1 \%$.ru

\&label linework

/* plot contacts and boundaries

linedelete all

lineset geology.lin

res $\%$ cover $1 \%$ arcs linecode gt 0 and linecode $1 t$ 40

arclines \%cover $1 \%$ linecode $\%$ cover $1 \%$.con

asel \%cover $1 \%$ arcs

linedelete all

lineset carto.lin 
res $\%$ cover $1 \%$ arcs linecode gt 40 and linecode lt 100

arclines \%cover $1 \%$ linecode $\%$ cover $1 \%$.con

asel $\%$ cover $1 \%$ arcs

\&label structure

$/ *$ plot faults and fold axes, etc. with line

patterns

linedelete all

lineset geology.lin

res \%cover $1 \%$ arcs linecode gt 100 and linecode

lt 600

arclines \%cover $1 \%$ linecode \%cover $1 \%$.str

asel $\%$ cover $1 \%$ arcs

\&label mapquad

/* plot quadrangle boundary

linedelete all

lineset plotter

linesymbol 5

$\operatorname{arcs} \%$ quad $\%$

/* plot state boundary

linedelete all

lineset carto.lin

res $\%$ cover $1 \%$ arcs linecode eq 71

arclines \%cover $1 \%$ linecode $\%$ cover $1 \%$.con

asel $\%$ cover $1 \%$ arcs

\&label geolabels

textsize 0.10

res $\%$ cover $1 \%$ poly area gt 300000

labeltext \%cover $1 \%$ unit \%cover $1 \%$.ru cc

asel $\%$ cover $1 \%$ poly

res $\%$ cover $1 \%$ poly unit $=226$

res \%cover $1 \%$ poly area gt 285000 and area le

300000

labeltext \%cover $1 \%$ unit \%cover $1 \%$.ru cc

asel $\%$ cover $1 \%$ poly

\&label points

/* plot points for map symbols

markerdelete all

markerset geology.mrk

pointmarkers \%pntcover\% symbol

/* plot annotation for all points

textset font.txt

/* annotext cover subclass \# $\{$ level...level $\}$

/*annotext \%pntcover\% dip \# 12

annotext \%pntcover\% dip \# 1

\&label titles

textfont 93715 textquality kern

textsize 0.5

move 1.527 .5

text 'U.S. DEPARTMENT OF THE INTERIOR'

move 1.526 .9

text 'U.S. GEOLOGICAL SURVEY'

move 3827.5

text 'Open-File Report 99-438' 1r

move 3826.9

text 'Plate 1' 1r

textfont 93711

textsize 0.7

move 16.22 .6

text 'Digital Geologic Map of part of the Thompson

Falls 1:100,000 quadrangle, Idaho' lc

textsize 0.5

move 16.22 .0

text 'by Reed S. Lewis and Pamela D. Derkey' lc

move 16.21 .2

text '1999' lc

\&label explan

/* plot explanation - geologic units

shadedelete all

shadeset calcomp1

textfont 93711

textsize 0.20

move 32.025 .7

text 'Explanation'

textsize 0.12

textquality proportional

textfont 94021

keyarea 32.017 .540 .425 .45

keybox 0.60 .35

keyseparation 0.20 .2

keyshade \%key $1 \%$ nobox

\&label linekey

/* plot explanation - line key

linedelete all

lineset geology.lin

keyarea 32.011 .040 .417 .4

keybox 0.60 .0

keyline \%key $2 \%$ nobox

\&label markers

/* plot explanation - marker key

markerdelete all

markerset geology.mrk

/*keyarea 32.011 .540 .410 .5

keymarker \%key3\% nobox

\&label refs

/* plot references 
textfont 93711

textsize 0.20

textcolor 1

move 32.011 .6

text 'References'

move 32.011 .4

textsize 0.12

textquality proportional

textfont 94021

textfile \%refs \%

\&label disclaimer

textfont 93713

textquality proportional

textsize 0.12

move 35.222 .2

textfile \%disclaimer\%

\&label credits

/*plot credits

textfont 94021

textquality proportional

textsize 0.12

move 25.53 .8

textfile \%credits\%

\&label proj

/*plot map projection notes

textfont 94021

textquality proportional

textsize 0.12

move 1.83 .7

text 'map projection: UTM, zone 11'

I* plot scale bars

linedelete all

lineset plotter

textfont 94021

textsize 0.12

\&r scale2a 4.772 .1 other 100000

\&label index-map

plot index_tf.gra box 32.04 .00356 .00

textfont 93713

textquality proportional

textsize 0.12

move 32.03 .95

text 'Index map showing Thompson Falls

quadrangle'

\&label lat-long

$1 *$ plot neat line labels (latitude and longitude)

mape \%quad $\%$

linecolor 1 mapprojection geo.prj u11.prj

neatline -116 47.5 -115 48.0 geo.prj

neatlinehatch 0.1250 .1250 .20 geo.prj

textset font.txt

textsymbol 1

textsize $8 \mathrm{pt}$

textstyle typeset

textoffset -0.350 .15$

neatlinelabels 0.125 top all geo.prj dms

'\%1\%!pat1857; \%2\%!pat1727; \%3\%!pat1728'

textoffset -0.750 .0$

neatlinelabels 0.125 left all geo.prj dms

'\%1\%!pat1857; \%2\%!pat1727; \%3\%!pat1728'

\&label done

quit

display 99993

draw tf100k

\&return 


\title{
Appendix D - Metadata (tf100k.met)
}

\author{
Identification_Information: \\ Citation: \\ Citation_Information: \\ Originator: Reed S. Lewis \\ Originator: Pamela D. Derkey \\ Publication_Date: 1999 \\ Title: \\ Digital geologic map of part of the Thompson Falls 1:100,000 quadrangle, \\ Idaho \\ Edition: version 1.0 \\ Geospatial_Data_Presentation_Form: map \\ Series_Information: \\ Series_Name: Open-File Report 99-438 \\ Issue_Identification: tf100k.e00, tfpnt.e00 \\ Publication_Information: \\ Publication_Place: Spokane WA \\ Publisher: U.S. Geological Survey \\ Online_Linkage: URL = http://wrgis.wr.usgs.gov/open-file/of99-438
}

\section{Description:}

Abstract:

The geology of the Thompson Falls 1:100,000 quadrangle, Idaho was compiled by Reed S. Lewis in 1997 onto a 1:100,000-scale topographic base map for input into an Arc/Info geographic information system (GIS). The digital geologic map database can be queried in many ways to produce a variety of derivative geologic maps.

Purpose:

This dataset was developed to provide geologic map GIS of the Idaho portion of the Thompson Falls 1:100,000 quadrangle for use in future spatial analysis by a variety of users.

This database is not meant to be used or displayed at any scale larger than 1:100,000 (e.g., 1:62,500 or 1:24,000).

Supplemental_Information:

This GIS consists of two major Arc/Info datasets: one line and polygon file (tf100k) containing geologic contacts and structures (lines) and geologic map rock units (polygons), and one point file (tfpnt) containing structural data.

Time_Period_of_Content:

Time_Period_Information:

Single_Date/Time:

Calendar_Date: 1999

Currentness_Reference: publication date

Status:

Progress: complete 
Maintenance_and_Update_Frequency:

Plan to update with a new geologic map data

model, perhaps in 2000.

Spatial_Domain:

Bounding_Coordinates:

West_Bounding_Coordinate: -116.0

East_Bounding_Coordinate: -115.0

North_Bounding_Coordinate: 48.00

South_Bounding_Coordinate: 47.50

Keywords:

Theme:

Theme_Keyword_Thesaurus: none

Theme_Keyword: geology

Theme_Keyword: geologic map

Place:

Place_Keyword_Thesaurus: none

Place_Keyword: Idaho

Place_Keyword: Thompson Falls

Place_Keyword: Shoshone County

Place_Keyword: Pacific Northwest

Place_Keyword: USA

Access_Constraints:

Use_Constraints:

This digital database is not meant to be used or displayed at any scale larger than 1:100,000 (e.g., 1:62,500 or 1:24,00).

Any hardcopies utilizing these data sets shall clearly indicate their source. If the user has modified the data in any way they are obligated to describe the types of modifications they have performed on the hardcopy map. User specifically agrees not to misrepresent these data sets, nor to imply that changes they made were approved by the U.S. Geological Survey.

Point_of_Contact:

Contact_Information:

Contact_Person_Primary:

Contact_Person: Pamela D. Derkey

Contact_Organization: U.S. Geological Survey

Contact_Position: geologist

Contact_Address:

Address_Type: mailing and physical address

Address: 904 W. Riverside Ave., Rm. 202

City: Spokane

State_or_Province: WA

Postal_Code: 99201

Country: USA

Contact_Voice_Telephone: 1-509-368-3114

Contact_Facsimile_Telephone: 1-509-368-3199

Contact_Electronic_Mail_Address: pderkey@usgs.gov 


\section{Data_Set_Credit:}

Reed S. Lewis (contractor) compiled the geology onto stable-base material;

Optronics Specialty Co., Inc. scanned the geologic map and provided minimally attributed Arc/Info interchange-format files to the USGS;

Pamela D. Derkey (USGS) imported the files, transformed them to UTM zone 11 (with a y-shift) and attached and attributed an interim geologic map data model;

Thomas P. Frost (USGS) visually compared the hard copy plots with the source;

Jon R. Oblad (EWU) annotated the point data for output at a scale of 1:100,000.

Native_Data_Set_Environment:

SunOS, 5.5.1, sun4u UNIX

ARC/INFO version 7.1.1

Data_Quality_Information:

Attribute_Accuracy:

Attribute_Accuracy_Report:

Attribute accuracy was verified by manual comparison

of the source with hard copy printouts and plots.

Logical_Consistency_Report:

Polygon and chain-node topology present.

Polygons intersecting the neatline are closed along the border.

Segments making up the outer and inner boundaries of a polygon tie end-to-end to completely enclose the area. Line segments are a set of sequentially numbered coordinate pairs. No duplicate features exist nor duplicate points in a data string. Intersecting lines are separated into individual line segments at the point of intersection. Point data are represented by two sets of coordinate pairs, each with the same coordinate values. All nodes are represented by a single coordinate pair which indicates the beginning or end of a line segment. The neatline was generated by mathematically generating the four sides of the quadrangle, densifying the lines of latitude and projecting the file to UTM zone 11 (with a y-shift).

\section{Completeness_Report:}

All geologic units were compiled from previously existing geologic maps ranging in scale from 1:24,000 to 1:250,000.

Positional_Accuracy:

Horizontal_Positional_Accuracy:

Horizontal_Positional_Accuracy_Report:

The horizontal positional accuracy for the digital data is no better than +/- 7 meters based on the transformation RMS error. It was tested by visual comparison of the source with hard copy plots.

\section{Lineage:}

Source_Information: 
Source_Citation:

Citation_Information:

Originator: Griggs, A.B.

Publication_Date: not published

Title:

Unpublished geologic maps of the Bloom Peak 7.5-, Burke 15-,

Cooper Gulch 15-, Gem Peak 7.5-, Noxon 7.5- and Taylor Peak

7.5-minute quadrangles, Idaho

Geospatial_Data_Presentation_Form: map

Publication_Information:

Publication_Place: Denver CO

Publisher: U.S. Geological Survey Field Records Library

Source_Scale_Denominator: 24,000

Source_Scale_Denominator: 62,500

Type_of_Source_Media: paper maps

Source_Time_Period_of_Content:

Time_Period_Information:

Single_Date/Time:

Calendar_Date: 1961-1969

Source_Currentness_Reference: date of field mapping

Source_Citation_Abbreviation: Griggs, unpublished field notes

Source_Contribution: These field maps were used in the map compilation.

Source_Information:

Source_Citation:

Citation_Information:

Originator: Harrison, J.E.

Originator: Griggs, A.B.

Originator: Wells, J.D.

Publication_Date: 1986

Title:

Geologic and structure maps of the Wallace 1- by 2-degree

quadrangle, Montana and Idaho

Geospatial_Data_Presentation_Form: map

Series_Information:

Series_Name: Miscellaneous Investigations Series

Issue_Identification: Map I-1509A

Publication_Information:

Publisher: U.S. Geological Survey

Source_Scale_Denominator: 250,000

Type_of_Source_Media: paper maps

Source_Time_Period_of_Content:

Time_Period_Information:

Single_Date/Time:

Calendar_Date: 1986

Source_Currentness_Reference: publication date

Source_Citation_Abbreviation: Harrison and others, 1986

Source_Contribution: This map was used in the map compilation.

Source_Information:

Source_Citation:

Citation_Information:

Originator: Hobbs, S.W.

Originator: Griggs, A.B.

Originator: Wallace, R.E.

Originator: Campbell, A.B. 
Publication_Date: 1965

Title: Geology of the Coeur d'Alene district

Geospatial_Data_Presentation_Form: map

Series_Information:

Issue_Identification: Professional Paper 478

Publication_Information:

Publisher: U.S. Geological Survey

Source_Scale_Denominator: 24,000

Type_of_Source_Media: paper maps

Source_Time_Period_of_Content:

Time_Period_Information:

Single_Date/Time:

Calendar_Date: 1965

Source_Currentness_Reference: publication date

Source_Citation_Abbreviation: Hobbs and others, 1965

Source_Contribution: These maps were used in the map compilation.

Source_Information:

Source_Citation:

Citation_Information:

Originator: Hosterman, J.W.

Publication_Date: 1956

Title: Geology of the Murray area, Shoshone County, Idaho

Geospatial_Data_Presentation_Form: map

Series_Information:

Issue_Identification: Bulletin 1027-P

Publication_Information:

Publisher: U.S. Geological Survey

Source_Scale_Denominator: 62,500

Type_of_Source_Media: paper map

Source_Time_Period_of_Content:

Time_Period_Information:

Single_Date/Time:

Calendar_Date: 1956

Source_Currentness_Reference: publication date

Source_Citation_Abbreviation: Hosterman, 1956

Source_Contribution: This map was used in the map compilation.

Source_Information:

Source_Citation:

Citation_Information:

Originator: Gibson, Russell

Originator: Jenks, W.F.

Originator: Campbell, Ian

Publication_Date: 1941

Title:

Stratigraphy of the Belt series in Libby and Trout

Creek quadrangles, northwestern Montana and northern

Idaho

Geospatial_Data_Presentation_Form: maps?

Series_Information:

Series_Name: Geological Society of America Bulletin

Issue_Identification: vol. 52, no. 3, p. 363-379

Publication_Information:

Publisher: Geological Society of America

Source_Scale_Denominator: 180,000 
Type_of_Source_Media: paper maps?

Source_Time_Period_of_Content:

Time_Period_Information:

Single_Date/Time:

Calendar_Date: 1941

Source_Currentness_Reference: publication date

Source_Citation_Abbreviation: Gibson and others, 1941

Source_Contribution:

This source was used as a secondary source in compiling

the geologic map.

Source_Information:

Source_Citation:

Citation_Information:

Originator: Ransome, F.L.

Originator: Calkins, F.C.

Publication_Date: 1908

Title:

The geology and ore deposits of the Coeur d'Alene

district, Idaho

Geospatial_Data_Presentation_Form: maps

Series_Information:

Issue_Identification: Professional Paper 62

Publication_Information:

Publisher: U.S. Geological Survey

Source_Scale_Denominator: 62,500

Type_of_Source_Media: paper map

Source_Time_Period_of_Content:

Time_Period_Information:

Single_Date/Time:

Calendar_Date: 1908

Source_Currentness_Reference: publication date

Source_Citation_Abbreviation: Ransome and Calkins, 1908

Source_Contribution: This map was used in the map compilation.

Source_Information:

Source_Citation:

Citation_Information:

Originator: Schalck, D.K.

Publication_Date: 1989

Title:

The geology and alteration of the Gem stocks, Shoshone

County, Idaho: in V.E. Chamberlain, R.M. Breckenridge,

and Bill Bonnichsen (editors), Guidebook to the geology

of northern and western Idaho and surrounding area

Geospatial_Data_Presentation_Form: map

Series_Information:

Issue_Identification: Bulletin 28

Publication_Information:

Publisher: Idaho Geological Survey

Publication_Place: Moscow, Idaho

Source_Scale_Denominator: unknown

Type_of_Source_Media: paper map

Source_Time_Period_of_Content:

Time_Period_Information:

Single_Date/Time: 
Calendar_Date: 1989

Source_Currentness_Reference: publication date

Source_Citation_Abbreviation: Schalck, 1989

Source_Contribution:

This source was used as a secondary source in compiling

the geologic map.

Source_Information:

Source_Citation:

Citation_Information:

Originator: U.S. Geological Survey

Publication_Date: 1993

Title:

1:100,000-scale digital line graph (DLG) data -

hydrography and transportation, Area 13 --

Northwestern states

Geospatial_Data_Presentation_Form: digital line graph (DLG) data

Series_Information:

Series_Name: US GeoData (optional format)

Publication_Information:

Publisher: U.S. Geological Survey

Source_Scale_Denominator: 100,000

Type_of_Source_Media: CD-ROM

Source_Time_Period_of_Content:

Time_Period_Information:

Single_Date/Time:

Calendar_Date: 1993

Source_Currentness_Reference: publication date

Source_Citation_Abbreviation: USGS, 1993

Source_Contribution:

This source provided the eastern boundary of the map

area (Idaho-Montana) boundary in a digital format.

Source_Information:

Source_Citation:

Citation_Information:

Originator: Shenon, P.J.

Publication_Date: 1938

Title: Geology and ore deposits near Murray, Idaho

Geospatial_Data_Presentation_Form: map?

Series_Information:

Issue_Identification: Pamphlet 47

Publication_Information:

Publication_Place: Moscow, Idaho

Publisher: Idaho Bureau of Mines and Geology

Source_Scale_Denominator: unknown

Type_of_Source_Media: paper map?

Source_Time_Period_of_Content:

Time_Period_Information:

Single_Date/Time:

Calendar_Date: 1938

Source_Currentness_Reference: publication date

Source_Citation_Abbreviation: Shenon, 1938

Source_Contribution:

This source was used as a secondary source in compiling

the geologic map. 
Source_Information:

Source_Citation:

Citation_Information:

Originator: Umpleby, J.B.

Originator: Jones, E.L., Jr.

Publication_Date: 1923

Title: Geology and ore deposits of Shoshone County, Idaho

Geospatial_Data_Presentation_Form: map

Series_Information:

Issue_Identification: Bulletin 732

Publication_Information:

Publisher: U.S. Geological Survey

Source_Scale_Denominator: 250,000

Type_of_Source_Media: paper map

Source_Time_Period_of_Content:

Time_Period_Information:

Single_Date/Time:

Calendar_Date: 1923

Source_Currentness_Reference: publication date

Source_Citation_Abbreviation: Umpleby and Jones, 1923

Source_Contribution:

This secondary source provided additional information

in compiling the geologic map.

Process_Step:

Process_Description:

Geologic map information from source maps were reduced to a

scale of 1:100,000 using a copy machine, then manually compiled onto a stable-base copy of the USGS 1:100,000-scale topographic

quadrangle map and manually labeled.

Process_Description:

Stable-base map was scanned and converted from

a raster to a vector format (in scanner units).

Process_Description:

Digital files were transformed to UTM zone 11 (meters),

with a RMS error (input,output $)=(0.003,7.350)$, and

attributed using an interim geologic map data model.

The data were checked for position by comparing plots

of the digital data to the source.

Process_Date: 1998

Spatial_Data_Organization_Information:

Direct_Spatial_Reference_Method: Vector

Point_and_Vector_Object_Information:

SDTS_Terms_Description:

SDTS_Point_and_Vector_Object_Type: Point

Point_and_Vector_Object_Count: 230

SDTS_Point_and_Vector_Object_Type: String

Point_and_Vector_Object_Count: 744

SDTS_Point_and_Vector_Object_Type: GT-polygon composed of chains

Point_and_Vector_Object_Count: 231

Spatial_Reference_Information:

Horizontal_Coordinate_System_Definition:

Planar: 
Grid_Coordinate_System:

Grid_Coordinate_System_Name: Universal Transverse Mercator Universal_Transverse_Mercator:

UTM_Zone_Number: 11

Transverse_Mercator:

Scale_Factor_at_Central_Meridian: implied

Longitude_of_Central_Meridian: implied

Latitude_of_Projection_Origin: implied

False_Easting: 0.000

False_Northing: $-5,000,000$ meters

Planar_Coordinate_Information:

Planar_Coordinate_Encoding_Method: coordinate pair

Coordinate_Representation:

Abscissa_Resolution: not determined

Ordinate_Resolution: not determined

Planar_Distance_Units: METERS

Geodetic_Model:

Horizontal_Datum_Name: North American Datum of 1927

Ellipsoid_Name: Clarke 1866

Semi-major_Axis: 6378206.4

Denominator_of_Flattening_Ratio: 294.98

Entity_and_Attribute_Information:

Overview_Description:

Entity_and_Attribute_Overview:

The 'Digital geologic map of part of the Thompson Falls 1:100,000

quadrangle, Idaho' Open-File Report 99-438 contains a detailed

description of each attribute code and a reference to the associated map symbols on the map source materials.

The GIS includes a geologic linework arc attribute table, tf100k.aat, that relates to the tf100k.con (contact look-up table), tf100k.str (structure look-up table), and tf100k.ref (source reference look-up table) files; a rock unit polygon attribute table, tf 100k.pat, that relates to the tf $100 \mathrm{k} . r u$ (rock unit look-up table) and tf100k.ref (source reference look-up table) files; and a geologic map symbol point attribute table, tfpnt.pat, that relates to the tfpnt.sym (structural point data look-up tables) and tfpnt.ref (source reference look-up table) files.

Entity_and_Attribute_Detail_Citation: see PDF of text on website.

Distribution_Information:

Distributor:

Contact_Information:

Contact_Organization_Primary:

Contact_Organization: U.S. Geological Survey Information Services

Contact_Address:

Address_Type: mailing and physical address

Address: Open-File Reports, Box 25286

City: Denver

State_or_Province: CO

Postal_Code: 80225

Country: USA

Contact_Voice_Telephone: 1-303-202-4200 
Contact_Facsimile_Telephone: 1-303-202-4695

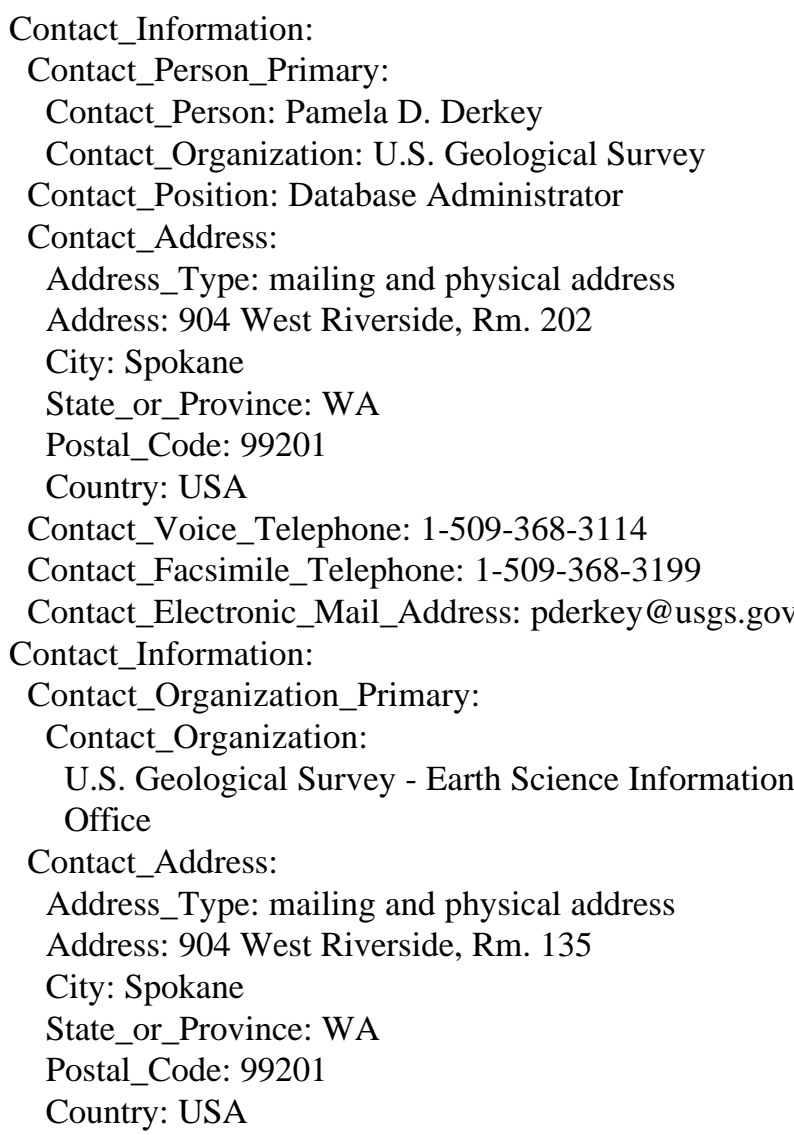

Contact_Voice_Telephone: 1-509-368-3130

Contact_Facsimile_Telephone: 1-509-368-3194

Contact_Electronic_Mail_Address: esnfic@mailmcan1.wr.usgs.gov

Hours_of_Service: 8:00 a.m. - 4:30 p.m., Pacific time zone

Distribution_Liability:

The U.S. Geological Survey (USGS) provides these geographic data "as is." The USGS makes no guarantee or warranty concerning the accuracy of information contained in the geographic data. The USGS further makes no warranties, either expressed or implied as to any other matter whatsoever, including, without limitation, the condition of the product, or its fitness for any particular purpose. The burden for determining fitness for use lies entirely with the user. Although these data have been processed successfully on computers at the USGS, no warranty, expressed or implied, is made by the USGS regarding the use of these data on any other system, nor does the fact of distribution constitute or imply any such warranty.

In no event shall the USGS have any liability whatsoever for payment of any consequential, incidental, indirect, special, or tort damages of any kind, including, but not limited to, any loss of profits arising out of use of or reliance on the geographic data or arising out of the delivery, installation, operation, or support by USGS.

This digital geologic map GIS of the Thompson Falls 1:100,000 quadrangle, Idaho, is not meant to be used or displayed at any scale larger than 1:100,000 (e.g., 1:62,500 or 1:24,000). 


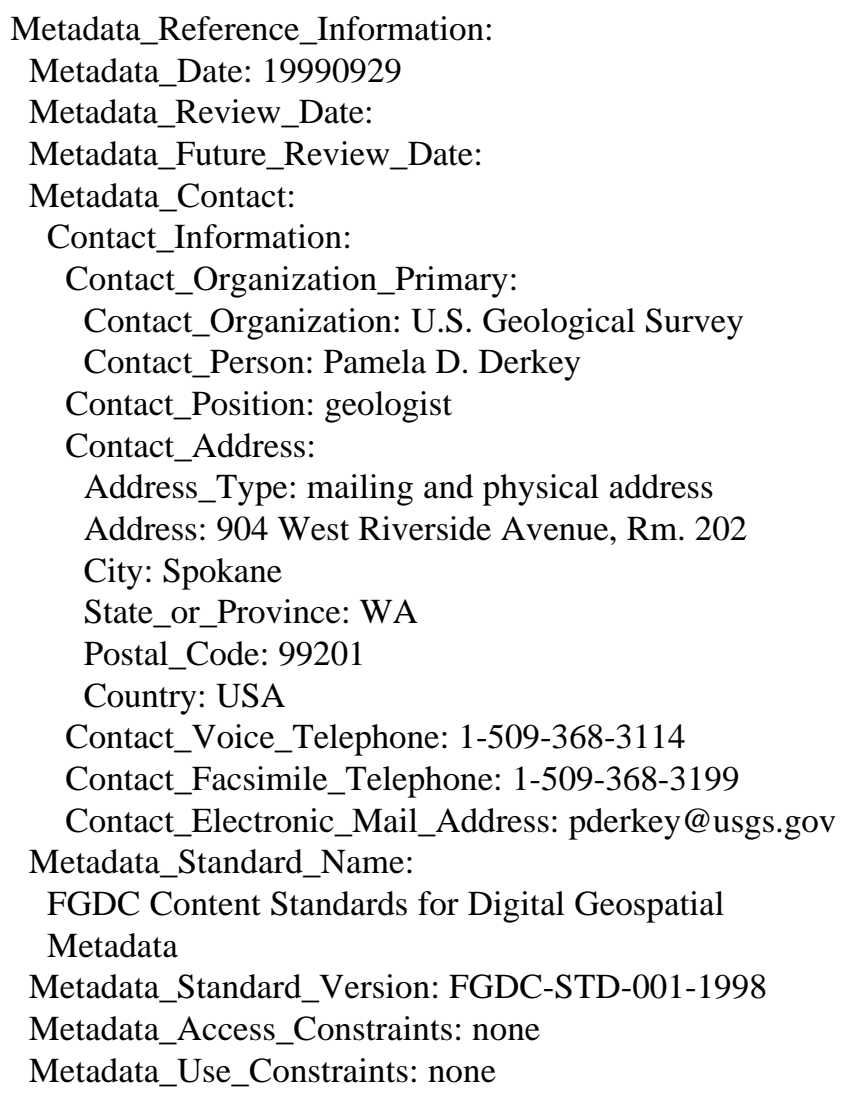

